Click www.researchjournal.co.in/online/subdetail.html to purchase.

\title{
Development of pomegranate arils separator
}

\author{
V.V. Malwade, S.R. Patil and A.K. Bhardwaj
}

Received : 21.05.2018; Revised : 07.08.2018; Accepted : 24.08.2018

See end of the Paper for authors' affiliation

Correspondence to :

V. V. Malwade

Department of Agricultural Engineering, Maharashtra Institute of Technology, Aurangabad (M.S.) India Email : vaibhav.malwade57@ gmail.com
ABSTRACT : Pomegranate is high demanding fruit due to its unique properties. It is an important fruit crop of arid and semiarid regions of the world and India is the leading producer of pomegranate in the world. As per the data available on national horticultural board the annual area and production of pomegranate fruit for Maharashtra state in year 2015-16 is 128.40 ('000 Ha) and 1486.11 ('000 MT), respectively. As pomegranate having leathery pericarp, it requires more time for manual separation approximately 8-10 minutes for one fruit. The various materials required for the development of pomegranate arils separator are cylinder, shaft, nylon rods, stationary rods, motor, sieve, cutting mechanism, speed regulator, cylinder supporting frame, arils collection tray, etc. The performance evaluation was carried out on the product basis. In these parameters like aril removal efficiency $(\%)$, aril unremoved (\%), mechanical waste $(\%)$ and capacity $(\mathrm{kg} / \mathrm{hr})$ of machine were calculated. The results of aril removal efficiency (\%), aril unremoved (\%), mechanical waste $(\%)$ and feeding capacity $(\mathrm{kg} / \mathrm{hr})$ were $76.18,23.80,14.10$ and $38.34 \mathrm{~kg} / \mathrm{hr}$ capacity at $250 \mathrm{RPM}$. The results performance was checked by using four different RPM like 150, 200, 250 and 300. In this 250 RPM was selected because it is observed that, as speed of motor increased at certain level it produced better results like high aril removal efficiency, high capacity and low mechanical waste than lower speed.

- KEY WORDS : Pomegranate, Arils, Pericarp, Sphericity, Probes, Compression, Texture profile analysis

-HOW TO CITE THIS PAPER : Malwade, V.V., Patil, S.R. and Bhardwaj,A.K. (2018). Development of pomegranate arils separator. Internat. J. Agric. Engg., 11(2) : 300-304, DOI: 10.15740/HAS/IJAE/ 11.2/300-304. Copyright@2018: Hind Agri-Horticultural Society. 